DOI: 10.12731/2077-1770-2017-4-227-247

\title{
АНАЛИЗ РЕПРЕЗЕНТАЦИИ КОНЦЕПТУАЛЬНОЙ КАРТИНЫ МИРА ЖИТЕЛЕЙ СЕВЕРА РОССИИ И НОРВЕГИИ
}

\section{Кобцева С.А.}

Цель. Статья посвящена описанию лингвокультурологического исследования концептуальной картины мира жителей северных регионов. Данное исследование основано на сравнительном анализе дискурса региональной прессы Мурманской области и Норвегии с результатами, полученными в ходе ассочиативных экспериментов в данных регионах. Целью данного исследования является сравнительно-сопоставительное изучение специфики репрезентации картины мира у носителей разных языков и культур, проживающих в условиях Арктического региона.

Метод или методология проведения работы. В работе применялись следующие методы исследования: элементы контентанализа текстов региональных СМИ с целью выявления ключевых кониептов; контекстуальный анализ текстов региональной прессы; ассоциативный эксперимент; количественная обработка материалов; сравнительный анализ и интерпретация полученных данных.

Результаты. Проведенное исследование позволило выделить ключевые кониепты языковой картины мира жителей севера России (Мурманская область) и Норвегии на основе анализа газетного дискурса, определить содержание и структуру одного из ключевых концептов ПОЛИТИКА и его репрезентацию в сознании представителей разных языков и культур (по материалам ассочииативных экспериментов), а также уточнить влияние общественно-политического дискурса на содержание и структуру культурных представлений у жителей Арктического региона. 
Область применения результатов. Материаль данного исследования могут быть востребованы и актуальны в области сравнительной культурологи, межкультурной коммуникации, а также в сфере сочиально-политического проектирования и прогнозирования.

Ключевые слова: северное сотрудничество; концептосфера; актуальный/ключевой концепт; национально-культурная специфика; концептуальная картина мира; ассоциативный эксперимент; смысловая структура; ассоциативное поле.

\section{ANALYSIS OF THE CONCEPTUAL WORLD VIEW OF THE NORTH RUSSIA AND NORWAY INHABITANTS}

\section{Kobtseva S.A.}

Purpose. The paper dwells on the linguo-culturological study of the conceptual world view of the inhabitants of northern regions. This study is based on a comparative analysis of the regional press discourse in Murmansk region and Norway with data obtained through the associative experiments in the above-mentioned regions. The purpose of this research is defined as a comparative study of the world view specifics that native speakers of different languages and cultures living in the Arctic region have.

Methodology. The following research methods were used in the work: elements of the content analysis of the regional mass media texts in order to identify key concepts; contextual analysis of regional newspaper discourse; associative experiment; quantitative processing of materials; comparative analysis and interpretation of the data obtained.

Results. The conducted research allowed:

1. to indentify the key concepts of the conceptual world picture of the north Russia (Murmansk region) and Norway inhabitants, based on the analysis of newspaper discours;

2. to determine the content and structure of one of the key concepts POLITICS and its representation in the minds of representatives of different languages and cultures (on the basis of associative experiments); 
3. to clarify the influence of socio-political discourse on the content and structure of cultural representations among residents of the Arctic region.

Practical implications. It is assumed that the materials of this study can be relevant and in demand in the field of comparative cultural studies, intercultural communication, as well as in the sphere of socio-political planning and forecasting.

Keywords: Nordic co-operation; conceptual sphere; actual/key concept; national-cultural identity; conceptual world view; associative experiment; semantic structure; associative field.

В то время как наблюдается напряжение в отношениях отдельных стран на федеральном уровне, возрастает взаимодействие отдельных регионов, которое представляется одной из наиболее актуальных тенденций развития международных отношений на современном этапе. Так, в странах Северной Европы широко распространилась практика многосторонней связи в различных областях общественной жизни, получившая название «северное сотрудничество» [2, с. 3]. Северное сотрудничество позволяет северным регионам европейских стран компенсировать недостатки периферийного положения и способствует проведению общей самостоятельной политики с сохранением политического суверенитета, экономической независимости и культурной идентичности стран региона, что дает возможность данным регионам отстаивать свои интересы [4, с. 23].

В связи с возрастающим интересом к северному сотрудничеству значительную роль играет процесс укрепления связей между странами, находящимися в данном регионе. Этот процесс, в том числе, строится на прикладных лингвистических исследованиях, позволяющих составить представление о концептосфере и когнитивном сознании нации в его культурной специфике и дающих возможность определить наиболее актуальные проблемы для жителей данных регионов.

Исследование данной проблемы осуществлялось группой авторов (Курганова Н.И., Тюркан Е.А., Кобцева С.А.) в рамках проекта 
РГНФ «Национально-культурная специфика языкового сознания жителей Арктического региона», который был осуществлен в 2015-2016 гг. и ставил своей целью изучение национально-культурной специфики репрезентации мира и проведение сравнительного исследования картин мира у жителей четырёх стран, проживающих в Арктическом регионе, включая Россию (Мурманская область), Норвегию, США (Аляска) и Канаду [11, с. 3-4].

В данной статье нас интересует в первую очередь сотрудничество на уровне северных регионов России (на примере Мурманской области) и Норвегии (на примере губернии Финнмарк), играющее немаловажную роль в процессе устойчивого развития и освоения Арктики. Две страны имеют общую сухопутную границу, являются экономическими партнерами, взаимодействуют друг с другом в Арктическом Совете. Правительство наших государств поддерживает устойчивую политику в отношении северных регионов, уделяя особое внимание углублению знаний, развитию бизнеса, инноваций, деловой активности и международного сотрудничества. Партнерство России и Норвегии имеет давнюю историю. И на современном этапе, несмотря на сложную политическую обстановку, в рамках регионального сотрудничества продолжают активно действовать совместные проекты в различных сферах: экономики, культуры, науки и образования [14].

На первом этапе нами был осуществлен сбор эмпирических данных путем концептуального анализа текстов СМИ северных регионов. Что касается Норвегии, она занимает одно из ведущих в мире мест по количеству периодических печатных изданий на душу населения. Среди крупнейших национальных газет выделяют ежедневные Verdens Gang (365 тыс. экземпляров), Afrenposten (250 тыс. экземпляров), Dagbladet (183 тыс. экземпляров). Норвежский газетный союз объединял 152 газеты в 1998 г. Однако большая часть изданий относится к региональной прессе [19].

Национальная пресса Норвегии представляет в основном национальные и международные новости. Последние зачастую являются перепечаткой статей зарубежных информационных агентств. 
Поскольку в ходе исследования нас в первую очередь интересовал характер влияния национальной культуры и географического фактора (условия Крайнего Севера) на функционирование языкового сознания, в сферу контент-анализа были включены преимущественно публикации регионального характера, представляющие национальный медийный дискурс.

В качестве материала исследования картины мира жителей Норвегии нами были взяты статьи о событиях местной жизни из ежедневной газеты Finnmarken - региональной газеты губернии Финнмарк. Эта провинция - самая северная и самая крупная административно-территориальная единица (норв. fylker) королевства Норвегии, расположенная за Полярным кругом и граничащая с Мурманской областью Российской Федерации на востоке. Несмотря на обширную территорию (больше Дании), плотность населения в регионе - самая низкая в Норвегии - всего 1,53 чел/км². Население - 74534 человек (1,6\% населения Норвегии) [19].

Газета издается 6 раз в неделю с 13 мая 1899 г. Центральный офис газеты находится в Вадсё, где проживает около 6000 человек, второй офис - в Киркенесе. Однако эта газета распространяется не только в Вадсё и Киркенесе, ее читает вся губерния Финнмарк: Тана, Вардё, Ботсфьорд и т.д. Ежедневный тираж газеты составляет более 7 тысяч экземпляров. В редакции работает порядка 45 человек, 13 из которых - профессиональные журналисты. имеет Finnmarken несколько разделов и рубрик.

Читатели могут найти в газете не только интересные и актуальнее статьи, но и частные объявления, прогноз погоды, поздравления, кроссворды, комиксы, телепрограмму и многое другое. У газеты нет определенной направленности, журналисты издания освещают разные темы - социальные, политические, бизнес-новости, новости культуры и спорта. Всего в газете от 24 до 32 страниц, т.к. объем издания во многом зависит от рекламы и от количества и объема актуальных статей. Стоит отметить, что Finnmarken пользуется большим спросом у рекламодателей. На страницах газеты можно увидеть рекламу товаров, предприятий и событий со всего севера 
Норвегии. В газете выделяются следующие постоянные рубрики: Новости, Дебаты Северной Норвегии, Спорт, Погода, Фотографии, Телевидение и радио [17].

Газета выходит шесть раз в неделю (кроме воскресенья). Таким образом, в базу данных вошли газетные материалы за период с 1 июня 2015 г. по 31 мая 2016 г. В общей сложности нами проанализировано 313 электронных выпусков газеты (2199 статей). По сезонам это выглядит следующим образом: лето 2015 г.- 493 статьи, осень 2015 г. - 615 статей, зима 2015-2016 гг. - 544 статьи, весна 2016 г. 547 статей. Характер выборки статей осуществлялся по двум критериям - источника информации и наличие географического фактора (регионального компонента) в материалах СМИ [11, с. 294].

Исследование специфики языкового сознания жителей Мурманской области как одного из северных регионов России осуществлялось Е.А. Тюркан на материалах газеты «Вечерний Мурманск», являющейся одним из крупнейших региональных изданий. Годовая выборка исследуемого материала составила 6471 статью, которые были отобраны методом сплошной выборки и подвержены дальнейшему контент-анализу [11, с. 200].

Проведение данных исследований потребовало разработки соответствующей методики и комплекса необходимых экспериментальных процедур, направленных на выделение ключевых концептов газетного дискурса и моделирование структурных параметров картины мира. Обработка материалов проводилась по методике Н.И. Кургановой, специально разработанной в рамках работы над проектом и подробно представленной в ряде монографий и статей $[7,8,9,10]$.

По данной методике нами был проведен анализ структурных параметров картины мира жителей Норвегии на базе газетного дискурса, который включал следующие процедуры:

1. Выделение ключевых концептов картины мира на материале сезонной выборки.

2. Моделирование когнитивной и полевой структуры ключевых концептов. 
3. Моделирование смысловой структуры ключевых концептов.

4. Выделение смысловых доминант в национальной картине мира на материале газетного дискурса [10, с. 17-18].

Поскольку «концепт - это единица коллективного знания/сознания, отправляющая к высшим духовным ценностям, имеющая языковое выражение и отмеченная этнокультурной спецификой» [1, c. 64], анализ текстов региональных СМИ и обработка полученных данных позволили достаточно полно и точно представить структуру концептуальной картины мира жителей северных регионов, а также выделить её доминантные концепты.

В нашей статье мы подробно остановимся на сравнительном анализе одного из ключевых концептов ПОЛИТИКА, т.к. данный концепт является актуальным, как в российской, так и в норвежской региональной прессе за исследуемый временной период.

Так, за данный временной период нами было проанализировано 2199 статей в газете Finnmarken на региональную тематику и 703 из них относится к концепту ПОЛИТИКА.

Основанием для выделения ключевых концептов был избран количественный фактор, т.е. три наиболее частотных рубрики за представленный период. Ключевыми актуальными концептами газетного дискурса северной Норвегии (по материалам годовой выборки) являются следующие:

ПОЛИТИКА (703 статьи);

КУЛЬТУРА (454 статьи);

ЭКОНОМИКА (443 статьи) [5, с. 296].

Далее нами выяснены наполнение ключевых концептов, их семантико-смысловая структура, что определялось методом контент-анализа. Основным критерием для выборки статей являлось наличие регионального компонента в газетном материале, позволяющего оптимально представить специфику картины мира жителей Норвегии.

Наполнение концепта ПОЛИТКА определялось на основе статистических расчетов (количество употреблений на количество публикаций) и представлено в таблице 1. 
Таблийа 1.

Когнитивная структура концепта ПОЛИТИКА (по материалам газеты Finnmarken (Finnmark dagblad); июнь 2015 - май 2016)

\begin{tabular}{|l|c|c|c|c|c|}
\hline Рубрика / концепт & Лето & Осень & Зима & Весна & Всего \\
\hline ПОЛИТИКА & $\mathbf{1 4 0}$ & $\mathbf{2 5 3}$ & $\mathbf{1 6 3}$ & $\mathbf{1 4 7}$ & $\mathbf{7 0 3}$ \\
\hline Местные органы власти/выборы & 64 & 125 & 38 & 41 & 268 \\
\hline Борьба с преступностью & 25 & 47 & 48 & 56 & 176 \\
\hline Правительственная политика & 16 & 19 & 16 & 13 & 64 \\
\hline Беженцы & 31 & 62 & 61 & 37 & 191 \\
\hline Свобода прессы & 4 & - & - & - & 4 \\
\hline
\end{tabular}

Таким образом, ключевой концепт ПОЛИТИКА прослеживается в рамках следующих тем: Местные органы власти/выборы, Беженцы, Борьба с преступностью, Правительственная политика, Свобода прессы [11, с. 298].

Что касается выявления компонентов концептосферы ПОЛИТИКА через призму материалов региональной российской прессы («Вечерний Мурманск»), то она представлена следующим образом:

Внутренняя политика. Деятельность думы - 53 статьи (36\%);

Внешняя политика. Международные контакты - 43 статьи (29\%); Политические акции, митинги, мероприятия - 29 статей (20\%); Выборы - 22 статьи (15\%) [13, с. 67-68].

Таким образом, мы наблюдаем определенное совпадение в компонентах концептосферы ПОЛИТИКА через призму региональной прессы. Как в России, так и в Норвегии наибольшее количество статей посвящены деятельности местных (а не федеральных) органов власти и выборам в региональные органы, что определено наибольшим интересом читателей к данной тематике.

При этом наглядно прослеживается тот факт, что политическая жизнь северной Норвегии представлена многочисленными событиями, в которых более активно, чем на севере России, участвует местное население. Годовая выборка концепта ПОЛИТИКА почти в 5 раз превышает аналогичную по Мурманской области (703 и 147 соответственно). Данный факт, на наш взгляд, демонстрирует большую политическую активность жителей северной Норвегии. 
Следует отметить также, что структура исследуемых концептов динамична - она существенно отличается в разных сезонах и даже месяцах. Наиболее частотными в различные периоды выступают разные когнитивные слои. И происходит это в зависимости от времени года, ситуации в стране и в мире.

Интересна динамика изменения когнитивного слоя Беженцы в рамках концепта ПОЛИТИКА. Так, если в начале осени 2015 г. данная тема представлялась в дискурсе СМИ как проблема расселения, обеспечения достойных условий проживания беженцев и их семей, помощь со стороны местного населения. Начиная с конца осени и в течение зимы-весны 2016 г. в местной прессе появляется масса статей об ухудшении криминогенной ситуации в стране, уголовных преступлениях, совершенных, в том числе беженцами. И пресса на это отреагировала появлением статей, которые мы условно объединили в смысловую доминанту Негативные последствия наплыва беженцев, которая становится одной из наиболее частотных доминант и формирует ядро концепта ПОЛИТИКА. Данная тема поднимается в рубрике Политика через следующие составляющие:

- страна находится в кризисной ситуации из-за огромного потока беженцев: опасность роста преступности и распространения болезней;

- обсуждение вопроса о закрытии грании со Швецией и Россией для беженцев вследствие того, что Норвегия несет колоссальные финансовые потери на их содержание;

- принятие решения о возвращении беженцев, не являющихся этническими сирийцами, на Родину и отказ от приема новых беженцев в страну;

- мобилизация и вооружение дополнительньх сил полиции в связи с напльвом беженцев и ростом преступности в их среде.

Таким образом, когнитивный слой Негативные последствия наплыва беженцев перемещается из периферийной зоны (лето 2015 г.) в приядерную зону (осень 2015 г. - зима 2016 г.), и, наконец, в ядерную зону концепта ПОЛИТИКА (весна 2016 г.). Подобные изменения выявлены и в структуре других ключевых концептов. 
В дополнение к анализу структурных параметров картины мира на базе газетного дискурса, нами был проведены ассоциативные эксперименты с целью создания наиболее полной и объективной репрезентации концептуальной картины мира жителей северных регионов, что дает нам возможность определить наиболее актуальные для них проблемы. Именно ассоциативный эксперимент как метод исследования, согласно А.А. Залевской, считается основным способом доступа к информационной базе человека, т.к. слово является средством выхода на индивидуальный образ мира [3, с. 3-5].

Целью данных ассоциативных экспериментов является изучение содержания и структуры представлений жителей крайнего севера о выделенных из материалов региональных СМИ ключевых и базовых концептах. Остановимся подробнее на ассоциативном эксперименте, демонстрирующем репрезентации концептуальной картины мира жителей Норвегии (в основном северных губерний). В рамках ассоциативного эксперимента нами опрошено 34 участника (респондента) трех возрастных групп: 16-25 лет - 11 человек; 26-50 лет - 11 человек; 51-70 лет - 12 человек [6, с. 24].

Интервьюирование частично проводилось лично во время посещения Норвегии в июле 2016 г. Кроме того, анкета была размещена на сайте http://webanketa.com и ее участникам предлагалось написать 5 слов, которые ассоциируются со следующими вербальными стимулами: Politikk, Økonomi, Kultur, Sport, Miljø [18]. Данные слова-стимулы были выбраны не случайно: они дублируют ключевые и базовые концепты, выделенные нами в результате анализа газетного дискурса Норвегии.

Официальным языком королевства Норвегия является норвежский. При этом существуют две разновидности литературного норвежского языка: букмол (норв. bokmål - «книжный язык») и нюнорск (норв. nynorsk - «новонорвежский»). Кроме того, жители Норвегии разговаривают на более 200 местных диалектах, которые существенно отличаются друг от друга и официально принятых разновидностей норвежского языка. В губернии Финнмарк значительную долю населения региона составляют саамы (около 24\%), 
язык которых признан официальным в данной губернии наравне с норвежским. Исходя из того, что букмол распространен гораздо больше и является основным языком приблизительно для 85-90\% жителей Норвегии, анкета нами была составлена именно на данном варианте норвежского языка [19].

Недостаточно большое количество опрошенных не позволило выделить возрастные группы при анализе результатов анкеты, но в дальнейшем мы постараемся определить общее и отличное в ассоциатах в зависимости от возрастных категорий.

В общей сложности участники анкеты выдали 795 ассоциатов по 5 вербальным стимулам: Politikk (171 ассоциативная реакция), Økonomi (168 ассоциативных реакций), Kultur (158 ассоциативных реакций), Miljø (145 ассоциативных реакций), Sport (153 ассоциативные реакции) [6, с. 24].

В результате анализа анкеты нами было выделено стереотипное ядро ассоциативного поля по пяти словам-стимулам в составе 7 наиболее частотных вербальных реакций на представленные вербальные стимулы. Далее, с целью реконструкции структурных параметров поля на концептуальном уровне нами был выделен набор базовых пропозицй, послуживших основой для классификации всех асоциатов поля по каждому стимулу, включая единичные реакции, что позволило выделить когнитивные слои ассоциативных полей.

В ходе обработки материалов ассоциативного эксперимента нами использовалась методика анализа ассоциативного поля (далее АП), разработанная Н.И. Кургановой и представленная в монографии «Смысловое поле при моделировании значения слова» [8] и ряде других публикаций $[7,9,10]$.

Остановимся подробнее на результатах ассоциативного эксперимента на стимул: Politikk/ политика. Нами было получено 171 ассоциативная реакция на словесный стимул «Politikk», ранжирование которых в порядке частотности позволило представить ассоциативное поле данного вербального стимула. Структурирование ассоциативного поля позволило выделить ядро и периферию. Ядро ассоциативного поля включает 84 ассоциата (49\%), периферия 
представлена немногочисленными и единичными реакциями общим количеством 87 ассоциатов, выраженных словом или словосочетанием, что составляет примерно $51 \%$ от всего объема поля. На основании этого было выделено стереотипное ядро ассоциативного поля, полученного на вербальный стимул «Politikk/Политика», представленное в таблице 2 [6, с. 26].

Таблицуа 2.

Стереотипное ядро АП «Politikk»

\begin{tabular}{|l|l|c|}
\hline \multicolumn{1}{|c|}{$\begin{array}{c}\text { Ассоциативные реакции } \\
\text { (вербальные ассоциаты) }\end{array}$} & Количество \\
\hline 1. & deтоkrati/демократия & 18 \\
\hline 2. & makt/власть & 17 \\
\hline 3. & valg/выборы & 16 \\
\hline 4. & parti/napmия & 12 \\
\hline $5-7$. & likestilling/pавенство & 7 \\
\hline $5-7$. & logn/ложь & 7 \\
\hline $5-7$. & flyktninger/беженць & 7 \\
\hline Всего & & $\mathbf{8 4}$ \\
\hline
\end{tabular}

В процессе моделирования когнитивной структуры смыслового поля слова «Politikk». С этой целью мы попытались уточнить тип связи между словом-стимулом и каждым ассоциатом поля, включая единичные реакции. Эта процедура позволила нам выделить набор базовых пропозиций, с целью последующей классификации всех ассоциатов поля. Далее, на основании ранжирования когнитивных слоев в соответствии с количественными данными нами была смоделирована когнитивная структура АП «Politikk/Политика».

В ходе моделирования полевой структуры АП «Politikk/Политика» нами были выделены ядерные и периферийные слои в структуре поля. Структуры границы ядра, приядерной зоны и периферии были определены следующим образом: ядро - более $10 \%$ от всего объема ассоциатов поля, приядерная зона - 5-10\% и периферия менее 5\% ассоциатов, полученных на заданный стимул. В итоге полевая структура АП «Politikk/Политика» может быть представлена следующим образом: 
Ядро: 95\%

Результаты - $17 \%$

Последствия - $16 \%$

Отношение - $16 \%$

Условия $-16 \%$

Люди $-16 \%$

Сущность - $14 \%$

\section{Приядерная часть:}

Нет

\section{Периферия: 5\%}

Оценка $-2 \%$

Виды - 2\%

Место - 1\% [11, с. 306-307].

Таким образом, полевая структура ассоциативного поля может быть представлена следующим образом:

\section{Полевая структура АП «Politikk/Политика»}

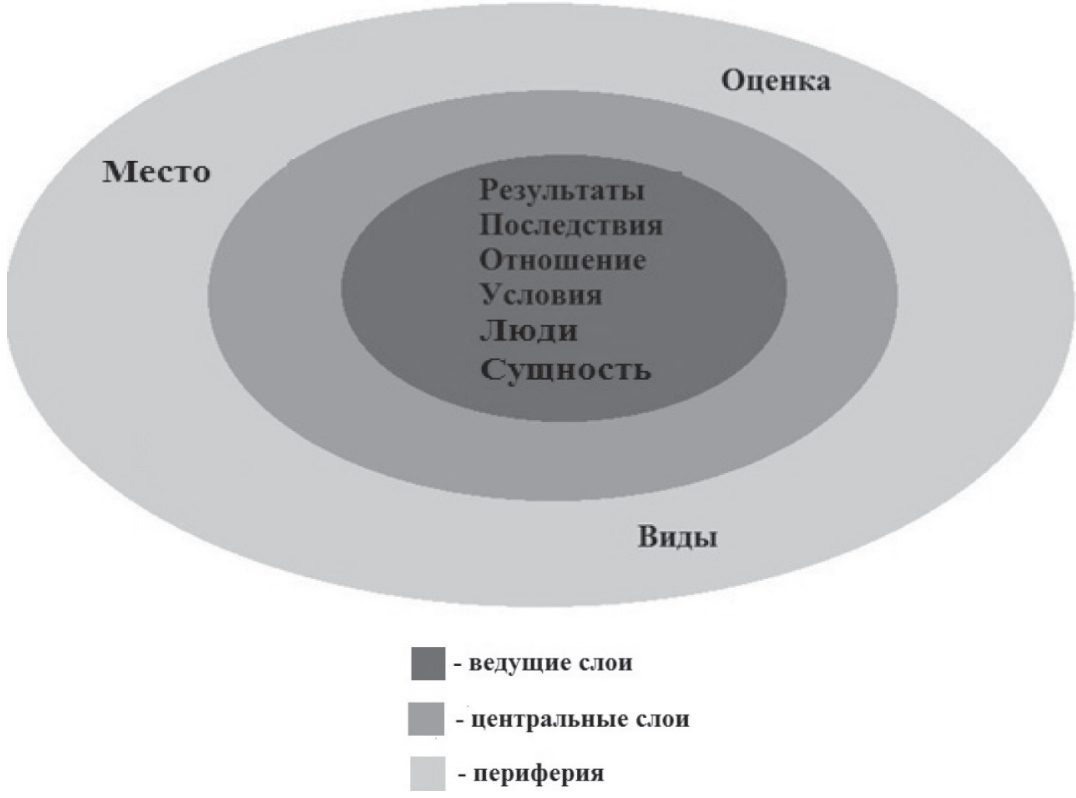


На основе сравнительного анализа когнитивной структуры ключевых концептов дискурса СМИ и когнитивных структур, выделенных по материалам ассоциативного поля «Politikk/Политика», наблюдается совпадение по ряду слоев: Valg/Bblбopbl, Flyktninger/ Беженцы (см. табл. 1, табл. 2). Данные слои являются смысловыми доминантами концепта ПОЛИТИКА по результатам анализа газетного дискурса Норвегии и, вместе с тем, входят в стереотипное ядро АП «Politikk/Политика» по результатам ассоциативного эксперимента, что доказывает тот факт, что данные позиции занимают ведущее место в языковом сознании жителей северной Норвегии.

Анализ результатов ассоциативного эксперимента среди возрастной группы от 18 до 25 лет по Мурманской области, проведенный в рамках исследования Е.А. Тюркан, позволил выделить стереотипное ядро ассоциативного поля на вербальный стимул политика, который выглядит следующим образом:

Таблицуа 3.

Стереотипное ядро АП «Политика»

\begin{tabular}{|l|l|c|}
\hline \multicolumn{1}{|c|}{$\begin{array}{c}\text { Ассоциативные реакции } \\
\text { (вербальные ассоциаты) }\end{array}$} & Количество \\
\hline 1. & выборы & 10 \\
\hline 2. & власть & 6 \\
\hline 3. & Путин & 5 \\
\hline $4-6$. & партия/партии & 4 \\
\hline $4-6$. & президент & 4 \\
\hline $4-6$. & грязь & 4 \\
\hline 7. & ложь & 3 \\
\hline Всего & $\mathbf{3 6}$ \\
\hline
\end{tabular}

Ранжирования когнитивных слоев в соответствии с количественными данными позволило смоделировать когнитивную структуру АП «Политика». В целом полевая смысловая структура АП «Политика» представляется следующим образом:

Ядро (более 10\%): $90 \%$

Люди $-30 \%$

Средство, инструмент $-23 \%$

Оценка/отношение - 14\% 
Место - $12 \%$

Результат $-11 \%$

Приядерная часть (5-10\%): 5\%

Последствия - 5\%

Периферия (менее 5\%): 5\%

Сущность - 3\%

Виды-2\% [11, с. 205-207].

Как мы видим, ядерные, приядерные и периферийные слои стимула политика, полученные в ходе АЭ в Норвегии и севера России (Мурманская область) существенно отличаются. Но, при этом наблюдается совпадения по ряду ассоциативных реакций: власть, выборы, партия. Так, политика ассоциируется у опрошенных через ее инструменты - прежде всего выборы, что показывает готовность населения данных регионов к предстоящим выборам.

Наличие ряда схожих ассоциативных реакций негативного характера на АП «Politikk/Политика», таких как грязь (4), ложь (3), вранье (2), обман, несправедливость, нечестность, фальшь, коррупция - Мурманская область и løgn/ложь (7), korrupsjon/корруnция (5), apartheid/anapmеид (2), lytter ikke til folk/не слушают людей (2), kiaos/xaоc (2), dele sin egen kake/делят свой пирог, svindel/мошенничество, teater/meamp, spill/uгp, иbarmhjertig/безжалостная, urettferdighet/несправедливость, inkoтреtanse/некомпетентность Норвегия, на наш взгляд, демонстрируют критическое отношение общества к политике государства в целом и политическим деятелям в частности в обоих исследуемых регионах [11, с. 206; 265].

Таким образом, на основе сравнительного анализа смысловых доминант ключевых концептов дискурса СМИ и когнитивных структур, выделенных по содержанию ассоциативных полей, полученных на вербальные стимулы в ходе ассоциативных экспериментов, проведенных в северных регионах Норвегии и России, наблюдается совпадение по ряду позиций.

Осуществление анализа структурных параметров картины мира на базе газетного дискурса, и проведение ассоциативных экспериментов помогает созданию наиболее полной и объективной ре- 
презентации концептуальной картины мира жителей северных регионов. Это дает возможность уточнить влияние общественно-политического дискурса на содержание и структуру культурных представлений у жителей Арктического региона, определить наиболее актуальные для данного региона проблемы и помочь в разработке стратегий их разрешения.

Исследование выполнено при финансовой поддержке РГНФ, в рамках научно-исследовательского проекта № 15-04-00465 «Национально-культурная специфика языкового сознания жителей Арктического региона».

\section{Список литературы}

1. Воркачев С.Г. Лингвокультурология, языковая личность, концепт: становление антропоцентрической парадигмы в языкознании // Филологические науки. 2001. № 1. С. 64-72.

2. Воронков Л.С. Страны Северной Европы. «Северное измерение» и Россия // Аналитические записки Научно-координационного совета по международным исследованиям МГИМО (У) МИД России. 2009. Вып. 1(41). С. 3-21.

3. Залевская А.А. Психолингвистические исследования. Слово. Текст: Избранные труды. М.: Гнозис, 2005. 543 с.

4. Исупова К.Б. Североевропейский регионализм как фактор сотрудничества с Европейским Союзом // Вестник Северного (Арктического) Федерального Университета. Серия: Гуманитарные и социальные науки. 2014. № 1. С. 23-26.

5. Кобцева С.А. Доминанты концептуальной картины мира жителей Северной Норвегии через призму региональных СМИ // Доминанты концептуальной картины мира жителей крайнего Севера: материалы научно-практического семинара с международным участием, 20 ноября 2015 г. Мурманск: МАГУ. 2015. С. 13-24.

6. Кобцева С.А. Доминанты концептуальной картины мира жителей Северной Норвегии (на основе данных ассоциативного эксперимента) // Актуальные проблемы лингвистики и методики преподавания 
иностранных языков: материалы межрегиональной научно-практической конференции, 28-29 ноября 2016 года. Мурманск: МАГУ. 2017. С. 22-30.

7. Курганова Н.И. Ассоциативный эксперимент как способ исследования национально-культурной специфики коллективного знания // Вестник Поморского гос. ун-та. 2011. № 7. Серия «Гуманитарные и социальные науки». С. 174-179.

8. Курганова Н.И. Смысловое поле при моделировании значения слова: монография. Мурманск: МГГУ, 2012. 162 с.

9. Курганова Н.И. Смысловое поле при моделировании структурных и операциональных параметров значения слова // Вестник Тверского гос. ун-та. 2012. № 29. Серия «Филология». Вып. 4 «Лингвистика и межкультурная коммуникация». С. 70-77.

10. Курганова Н.И. Картина мира жителей Канады через призму газетного дискурса // Доминанты концептуальной картины мира жителей крайнего Севера: материалы научно-практического семинара с международным участием, 20 ноября 2015 г. Мурманск: МАГУ, 2015. С. 13-24.

11. Курганова Н.И., Тюркан Е.А., Кобцева С.А. Национально-культурная специфика языкового сознания жителей Арктического региона. Мурманск: МАГУ, 2017. 352 с.

12. Тюркан Е.А. Актуальные концепты как доминанты концептуальной картины мира жителей Мурманской области и Аляски // Доминанты концептуальной картины мира жителей крайнего Севера: материалы научно-практического семинара с международным участием, 20 ноября 2015 г. Мурманск: МАГУ, 2015. С. 127-140.

13. Тюркан Е.А. Концептосфера ПОЛИТИКА в газетном дискурсе Аляски и Мурманской области // Актуальные проблемы лингвистики и методики преподавания иностранных языков: материалы межрегиональной научно-практической конференции, 28-29 ноября 2016 года. Мурманск: МАГУ, 2017. С. 62-80.

14. Российско-норвежские отношения // Посольство Российской Федерации в Норвегии URL: http://www.norway.mid.ru/ru/rn-politics.html (дата обращения 29.11.2015). 
15. VII Международная студенческая электронная научная конференция «Студенческий научный форум - 2015» URL: https://www. scienceforum.ru/2015/1079/14658 (дата обращения 17.01. 2016).

16. b-port. Сайт. URL: http://www.b-port.com/index/item/21055.html (дата обращения 28.08.2015).

17.iFinnmark. Сайт. URL: http://www.ifinnmark.no (дата обращения 24.04. 2016).

18. Webanketa URL: http://webanketa.com/ru/myforms/?sessid=d1bf821c8a e3dfa3d2a20a057838c00f6a3527011dk (дата обращения 12.12. 2016).

19. Sprakradet. Сайт. URL: http://www.sprakradet.no/Fakta/ (дата обращения 22.10.2016).

\section{References}

1. Vorkachev S.G. Filologicheskie nauki [Philological sciences], no1 (2001): 64-72.

2. Voronkov L.S. Strany Severnoj Evropy. «Severnoe izmerenie» i Rossija [The countries of Northern Europe. 'The Northern Dimension' and Russia]. Analiticheskie zapiski Nauchno-koordinatsionnogo soveta po mezhdunarodnym issledovaniyam MGIMO (U) MID Rossii [Analytical notes of the Scientific Coordination Council for International Studies of the Moscow State Institute of International Relations (University) of the Ministry of Foreign Affairs of Russia], no 1(41) (2009), pp. 3-21.

3. Zalevskaya A.A. Psikholingvisticheskie issledovaniya. Slovo. Tekst: Izbrannye trudy [Psycholinguistic research. Word. Text: Selected Works]. M.: Gnozis Publ., 2005. 543 p.

4. Isupova K.B. Severoevropejskij regionalizm kak faktor sotrudnichestva s Evropejskim Sojuzom [Northern European regionalism as a factor of cooperation with the European Union]. Vestnik Severnogo (Arkticheskogo) Federal'nogo Universiteta. Seriya: Gumanitarnye i sotsial'nye nauki [Bulletin of the Northern (Arctic) Federal University. Series: Humanities and Social Sciences], no 1 (2014), pp. 23-26.

5. Kobtseva S.A. Dominanty kontseptual'noy kartiny mira zhiteley kraynego Severa: materialy nauchno-prakticheskogo seminara s mezhdunarodnym uchastiem, 20 noyabrya 2015 [Dominants of the conceptual 
picture of the world of the inhabitants of the Far North: materials of the scientific and practical seminar with international participation, November 20, 2015], Murmansk, 2015, pp. 13-24.

6. Kobtseva S.A. Dominanty konceptual'noj kartiny mira zhitelej Severnoj Norvegii (na osnove dannyh associativnogo jeksperimenta) [Dominants of the conceptual world view of the inhabitants of Northern Norway (based on the data of the associative experiment)]. Aktual'nye problemy lingvistiki i metodiki prepodavaniya inostrannykh yazykov: materialy mezhregional'noy nauchno-prakticheskoy konferentsii, 28-29 noyabrya 2016 goda [Actual problems of linguistics and methods of teaching foreign languages: materials of the interregional scientific and practical conference, November 28-29, 2016], Murmansk, 2017, pp. 22-30.

7. Kurganova N.I. Associativnyj jeksperiment kak sposob issledovanija nacional'no-kul'turnoj specifiki kollektivnogo znanija [Associative experiment as a way to study the national and cultural specifics of collective knowledge].Vestnik Pomorskogo gos. un-ta [Bulletin of the Pomorian State University. Series "Humanities and Social Sciences"], no 1 (2011), pp. 174-179.

8. Kurganova N.I. Smyslovoe pole pri modelirovanii znacheniya slova: monografiya [Semantic field for modeling the meaning of a word: monograph]. Murmansk: MSHU Publ., 2012. 162 p.

9. Kurganova N.I. Smyslovoe pole pri modelirovanii strukturnyh i operacional'nyh parametrov znachenija slova [The semantic field in modeling the structural and operational parameters of the meaning of a word]. Vestnik Tverskogo gos. un-ta. [Bulletin of Tver State University], no 29 (2012), pp. 70-77.

10. Kurganova N.I. Kartina mira zhitelej Kanady cherez prizmu gazetnogo diskursa [The world view of the inhabitants of Canada through the prism of newspaper discourse]. Dominanty kontseptual'noy kartiny mira zhiteley kraynego Severa: materialy nauchno-prakticheskogo seminara s mezhdunarodnym uchastiem, 20 noyabrya 2015 [Dominants of the conceptual picture of the world of the inhabitants of the Far North: materials of the scientific and practical seminar with international participation, November 20, 2015]. Murmansk, 2015, pp. 13-24. 
11. Kurganova N.I., Tyurkan E.A., Kobtseva S.A. Natsional'no-kul'turnaya spetsifika yazykovogo soznaniya zhiteley Arkticheskogo regiona [National-cultural identity of linguistic consciousness of the inhabitants of the Arctic region]. Murmansk: MASU Publ., 2017. 352 p.

12.Tyurkan E.A. Aktual'nye koncepty kak dominanty konceptual'noj kartiny mira zhitelej Murmanskoj oblasti i Aljaski [Currently central concepts as dominants of the conceptual world view of residents of the Murmansk region and Alaska]. Dominanty kontseptual'noy kartiny mira zhiteley kraynego Severa: materialy nauchno-prakticheskogo seminara s mezhdunarodnym uchastiem, 20 noyabrya 2015 [Dominants of the conceptual picture of the world of the inhabitants of the Far North: materials of the scientific and practical seminar with international participation, November 20, 2015], Murmansk, 2015, pp. 127-140.

13. Tyurkan E.A. Konceptosfera POLITIKA v gazetnom diskurse Aljaski i Murmanskoj oblasti [Conceptual sphere POLITICS in the newspaper discourse of Alaska and the Murmansk region]. Aktual'nye problemy lingvistiki i metodiki prepodavaniya inostrannykh yazykov: materialy mezhregional'noy nauchno-prakticheskoy konferentsii, 28-29 noyabrya 2016 goda [Topical issues of linguistics and methods of teaching foreign languages: materials of the interregional scientific and practical conference, November 28-29, 2016], Murmansk, 2017, pp. 62-80.

14. Posol'stvo Rossiyskoy Federatsii v Norvegii [Embassy of the Russian Federation in Norway]. http://www.norway.mid.ru/ru/rn-politics.html (accessed November 29, 2015).

15. VII Mezhdunarodnaya studencheskaya elektronnaya nauchnaya konferentsiya «Studencheskiy nauchnyy forum 2015» [VII International Student Electronic Scientific Conference "Student Scientific Forum 2015”] https:// www.scienceforum.ru/2015/1079/14658 (accessed January 1, 2016).

16. b-port. http://www.b-port.com/index/item/21055.html (accessed August 28, 2015).

17.iFinnmark. http://www.ifinnmark.no (accessed April 24, 2016).

18. Webanketa. http://webanketa.com/ru/myforms/?sessid=d1bf821c8ae3dfa3d2a20a057838c00f6a3527011dk (accessed December 12, 2016).

19. Sprakradet. http://www.sprakradet.no/Fakta/ (accessed October 22, 2016). 


\section{ДАННЫЕ ОБ АВТОРЕ}

Кобцева Светлана Александровна, доцент кафедры иностранных языков социально-гуманитарного института, кандидат педагогических наук

Мурманский арктический государственный университет ул. Капитана Егорова, 15, г. Мурманск, Мурманская область, 183038, Российская Федерациия

kobtseva@yandex.ru

\section{DATA ABOUT THE AUTHOR}

Kobtseva Svetlana Aleksandrovna, Associate Professor of the Modern

Languages Department, Institute of the Humanities and Social Sciences, PhD in Education

Murmansk Arctic State University

15, captain Egorov Str., Murmansk, Murmansk Region, 183038, Russian Federation

kobtseva@yandex.ru

SPIN-code: 5135-0256

ORCID: 0000-0002-5534-9918 